\title{
Causes of Early Age Cracking on Concrete Bridge Deck Expansion Joint Repair Sections
}

\author{
Jared R. Wright, ${ }^{1}$ Farshad Rajabipour, ${ }^{2}$ Jeffrey A. Laman, ${ }^{3}$ and Aleksandra Radlińska ${ }^{4}$ \\ ${ }^{1}$ Department of Civil and Environmental Engineering, The Pennsylvania State University, 3127 Research Drive, \\ State College, PA 16801, USA \\ ${ }^{2}$ Department of Civil and Environmental Engineering, The Pennsylvania State University, 231M Sackett Building, \\ University Park, PA 16802, USA \\ ${ }^{3}$ Department of Civil and Environmental Engineering, The Pennsylvania State University, 231J Sackett Building, \\ University Park, PA 16802, USA \\ ${ }^{4}$ Department of Civil and Environmental Engineering, The Pennsylvania State University, 231D Sackett Building, \\ University Park, PA 16802, USA
}

Correspondence should be addressed to Jared R. Wright; jared.wright.4@gmail.com

Received 7 October 2013; Revised 6 February 2014; Accepted 11 February 2014; Published 17 March 2014

Academic Editor: Andreas Kappos

Copyright (C) 2014 Jared R. Wright et al. This is an open access article distributed under the Creative Commons Attribution License, which permits unrestricted use, distribution, and reproduction in any medium, provided the original work is properly cited.

Cracking of newly placed binary Portland cement-slag concrete adjacent to bridge deck expansion dam replacements has been observed on several newly rehabilitated sections of bridge decks. This paper investigates the causes of cracking by assessing the concrete mixtures specified for bridge deck rehabilitation projects, as well as reviewing the structural design of decks and the construction and curing methods implemented by the contractors. The work consists of (1) a comprehensive literature review of the causes of cracking on bridge decks, (2) a review of previous bridge deck rehabilitation projects that experienced early-age cracking along with construction observations of active deck rehabilitation projects, and (3) an experimental evaluation of the two most commonly used bridge deck concrete mixtures. Based on the literature review, the causes of concrete bridge deck cracking can be classified into three categories: concrete material properties, construction practices, and structural design factors. The most likely causes of the observed early-age cracking were found to be inadequate curing and failure to properly eliminate the risk of plastic shrinkage cracking. These results underscore the significance of proper moist curing methods for concrete bridge decks, including repair sections. This document also provides a blueprint for future researchers to investigate early-age cracking of concrete structures.

\section{Introduction}

Longitudinal early age cracking of concrete repair sections adjacent to bridge deck expansion dam replacements (Figure 1) has been observed on several newly rehabilitated bridge decks. This research was aimed at assessing the causes of cracking in these full-depth concrete repair sections and creating a methodology to quantify these causes. Transverse early age cracking of concrete bridge decks has been a common problem reported by many state DOTs [1-11]. Although many studies have been performed since the 1980s to identify the causes and effective mitigation practices for early age cracking on concrete bridge decks, very few studies have focused on cracking in repair sections, especially next to rehabilitated deck expansion dams. The published literature addressing cracking in deck repair sections is limited [1217] and focuses mostly on closure pour acceleration [12], complete shear failure of reinforcing steel [14], or the durability of specific repair materials such as polymer-modified cementitious concrete and epoxy-binder concretes [15-17]. This paper evaluates the causes of the observed longitudinal cracking by assessing the effect of concrete material properties, construction and curing practices, and structural design of repair sections. The authors maintain that the longitudinal early age cracking observed in repair sections near bridge deck dams is similar in nature to the transverse cracking of 


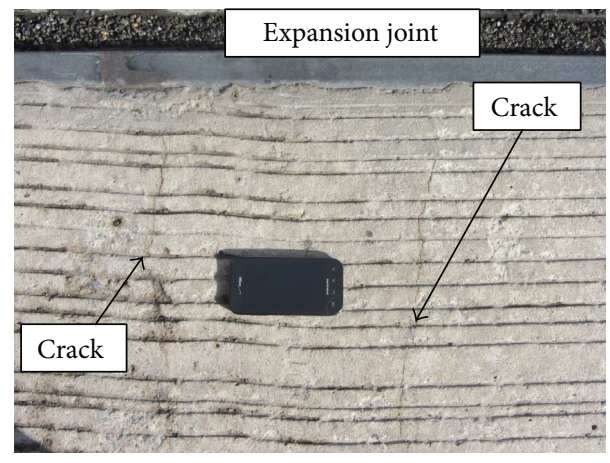

FIGURE 1: Early age longitudinal concrete cracking on concrete adjacent to bridge deck dam rehabilitations (cell phone: $4.5 \times 2$ inches for comparison).

newly constructed bridge decks. Restrained shrinkage and thermal contraction result in tensile stress development in concrete with the potential of cracking that is predominantly in the direction perpendicular to the longest dimension of the concrete member (i.e., transverse for full bridge decks and longitudinal for dam repair sections).

\section{Research Objective}

The main objective of this research is to identify the causes of longitudinal early age cracking in concrete deck segments placed adjacent to the newly replaced bridge deck expansion joints. This study satisfies this objective via a three-part investigation into the cracking propensity of concrete repairs on bridge decks placed in the recent decade through a case study involving bridge decks in Pennsylvania. These three parts consist of (1) a comprehensive literature review, (2) a review of past bridge deck rehabilitation projects that experienced early age cracking and construction inspection of active bridge dam rehabilitation projects, and (3) an experimental evaluation of the fresh and hardened properties of concrete in the laboratory to quantify the risk of cracking of the two most commonly used concrete mixtures for bridge deck construction and rehabilitation. This three-part investigation can then be utilized by other researchers to investigate early age cracking occurrences on bridges under their purview.

\section{Literature Review}

The factors that affect early age cracking on concrete bridge decks are divided into three categories: (1) concrete material properties, (2) construction practices, and (3) structural design factors. Each section that follows identifies the primary and secondary contributors to early age concrete cracking on bridge decks.

3.1. Concrete Material Properties. Concrete material properties have been the subject of the majority of past research for the mitigation of early age cracking on bridge decks. Excessive slump [2, 5-7, 18, 19], excessive cement content $[2,5-7,18-23]$, and excessive compressive strength $[4,6,22]$ are commonly recognized as the primary contributors to the early age cracking of concrete. Fiber reinforcement $[6,11,24-$ 27] significantly reduces concrete cracking.

Previous research shows a clear correlation between slump and the tendency of concrete to crack at early ages [10, $24,28]$. Increased slump can increase the settlement of fresh concrete over reinforcing bars and result in cracking [10]. Maximum allowable slump values of $50 \mathrm{~mm}$ [29], $63.5 \mathrm{~mm}$ [30], or 89-100 $\mathrm{mm}$ [7] have been proposed.

There is a strong positive relationship between concrete cracking and increased cement content [6, 10, 20]. Cement paste is the phase in concrete that undergoes shrinkage, while aggregates do not shrink and have a lower coefficient of thermal expansion. In addition, high cement content results in higher heat of hydration and increased risk of thermal cracking $[6,18]$. The maximum recommended cement content to prevent early age cracking has been reported as 362 to $430 \mathrm{~kg} / \mathrm{m}^{3}$ of concrete. However, 297 to $320 \mathrm{~kg} / \mathrm{m}^{3}$ is also noted to do the trick [7]. The literature also recommends a cement paste fraction not greater than 0.35 , including air content $[6,10](27 \%$ if excluding air content [7]).

An increase in the compressive strength of concrete is usually achieved by increasing the cement content and reducing the water to cementitious materials ratio $(\mathrm{w} / \mathrm{cm})$, which results in higher heat of hydration [31-33] and higher drying and autogenous shrinkage, as well as higher modulus of elasticity and lower creep $[6,23,34]$. A higher modulus and lower creep result in higher tensile stresses from shrinkage $[6,23,34]$. In addition, lower $\mathrm{w} / \mathrm{cm}$ increases the need for proper moist curing due to lack of bleed water, which results in higher risk of plastic shrinkage cracking [2]. Several studies have recommended narrowing the range of allowable w/cm to reduce cracking, as mixtures with too low or too high $\mathrm{w} / \mathrm{cm}$ have been shown to be more susceptible to cracking $[10,21,30,35]$. Allowable $\mathrm{w} / \mathrm{cm}$ in the range 0.40 [5] to 0.48 [29] has been suggested, with a more recent study suggesting a w/ cm in the range 0.42 to 0.45 [7]. Concrete strength much higher than that specified by structural design should not be permitted, as it exacerbates cracking [4].

Other factors that affect the heat of hydration and risk of thermal cracking include cement type and fineness, batching temperature, ambient temperature and solar radiation [30], and coefficient of thermal expansion of concrete [31,3640]. Secondary concrete material properties that are known to modestly influence early age cracking are aggregate type $[1,6,7,18,21]$, cement type $[2,6]$, air content $[6,9,21,22]$, use of mineral admixtures $[6,22,31,41-46]$, type of chemical admixtures $[6,7,11,22,46-51]$, and concrete properties such as Poisson's ratio [6] and thermal conductivity [31, 40].

3.2. Construction Practices. Construction methods and site ambient conditions can contribute to early age cracking of concrete. Inadequate moist curing [4, 6, 7, 10, 11, 45], insufficient compaction $[6,7,52]$, and ambient conditions that promote rapid evaporation of bleed water $[5,6,41,53-$ 55] contribute the most to early age cracking.

Insufficient vibration of concrete together with insufficient cover thickness over top reinforcement can increase 
plastic and settlement cracking [52]. This is especially significant for concrete with high water content and high slump. Undervibration of concrete tends to cause an increase in cracking, while overvibration has little effect [6]. A wellgraded mix may mitigate these effects.

Plastic shrinkage cracking is directly related to the evaporation rate of bleed water from the surface of fresh concrete $[36,53,55]$. Plastic cracks occur when the bleed water evaporates faster than the rate of bleeding, and as such, the surface of fresh concrete dries, resulting in capillary tensile stresses [51]. Evaporation rate is a function of the ambient relative humidity, concrete and air temperatures, and wind speed and can be estimated based on the nomograph in ACI 308R-01 [53]. Special considerations such as installing wind breaks or fog sprayers should be implemented when evaporation rates exceed $1 \mathrm{~kg} / \mathrm{m}^{2} / \mathrm{hr}$ for normal concrete and $0.5 \mathrm{~kg} / \mathrm{m}^{2} / \mathrm{hr}$ for concrete with low w/ $\mathrm{cm}[6]$.

Proper moist curing reduces cracking caused by plastic shrinkage in fresh concrete. Delayed curing tends to increase the cracking risk. Also, use of chemical evaporation retarders can help to decrease the number of cracks formed before the start of moist curing. Curing should begin immediately after finishing $[6,10,45]$. When wet burlaps are used, the first layer of presoaked burlap should be applied 10 minutes after strikeoff, with the application of a second layer within 5 additional minutes [7]. Moist curing should continue for a minimum of 7 days [4], but 14 days is preferred [56].

The sequence and length of concrete deck placement can have some (secondary) contribution to early age cracking $[22,35,52]$. This, however, is primarily relevant in continuous multispan bridges where flexural cracking can appear in negative moment regions caused by the dead load of concrete that is subsequently placed in the positive moment area [52]. Unless due to a mistake in structural design of the deck, tensile stresses caused by dead and live loads on the bridge are far smaller than the restrained shrinkage stresses and are unlikely to result in early age cracking $[6,10,20]$. Vibrations due to adjacent traffic lanes will only contribute to plastic cracking when concrete is undervibrated or has too high of slump [52].

3.3. Structural Design Factors. Structural design factors that are recognized as primary contributors to early age concrete deck cracking include inadequate cover thickness $[6,10]$ and improper reinforcing bar sizes and spacing $[4-6,10,20,21$, $28,37,57]$. A top cover depth of $50-75 \mathrm{~mm}$ on monolithic bridge decks has exhibited the least amount of cracking [10]. At least a $50 \mathrm{~mm}$ concrete cover is necessary to avoid settlement cracking [6]. Increasing the reinforcement bar size and spacing increases the cracking risk of bridge decks $[5,10,25,58]$. The use of a maximum bar size of \# 5 and maximum bar spacing of $150 \mathrm{~mm}$ has been recommended $[4,5,35]$.

Secondary structural design factors that influence early age deck cracking include bridge structure type [10], bridge deck type $[4,6,10,59]$, deck thickness $[5,6,9,20,21,29,35]$, deck end conditions $[4,10,20]$, girder type $[6,10,20,45]$, and mechanical loading $[4,6,10,20]$. Review of the joint detail will assist in this part of the investigation.

\section{Review of Past and Active Deck Rehabilitation Projects}

This section provides the information obtained from site visits to 11 past bridge deck expansion dam rehabilitation projects and 2 active deck dam rehabilitation projects in Pennsylvania. The variables considered by the research team during these site visits include the following:

(1) concrete mixture proportions and material properties: $\mathrm{w} / \mathrm{cm}$, cementitious materials content, cement type, aggregate type and content, mineral and chemical admixtures, plastic air content, slump (design and measured at site), and 28-day compressive strength (structural design, minimum required by job specifications, and laboratory test results);

(2) construction and curing practices: removal of old dam and adjacent concrete, cleaning and preparing the repair area, cleaning and epoxy coating of existing rebar within the repair area, installing new dam and additional rebar, placement, compacting and finishing concrete, ambient air temperature, relative humidity and wind speed, concrete temperature at placement, curing methods, and duration;

(3) structural design factors: reinforcing bar size and spacing and cover thickness.

The most important findings are provided below.

4.1. Concrete Material Properties. Records showed that the past projects' concrete mixtures yielded laboratory tested 28 day compressive strength results of up to $39.4 \mathrm{MPa}$, which is $43 \%$ higher than the strength required by the structural design $(27.6 \mathrm{MPa})$ and $27 \%$ higher than the strength required by the job specifications (31.0 MPa). A similar observation was made during the review of active projects. The excessive strength of concrete makes it more prone to early age cracking due to a higher shrinkage, higher stiffness, and lower capacity for creep and stress relaxation. The slumps measured were in excess of $200 \mathrm{~mm}$, which is in contrast with the literature recommendations of $50-100 \mathrm{~mm}[7,10,29,52,57]$. This excessive slump can contribute to settlement cracking. To prevent such occurrences in the future, the authors recommend enforcing a maximum allowable slump and a maximum allowable 28day compressive strength, which should not be considerably higher than the minimum slump and strength required in the project specifications.

4.2. Construction Practices. During observation of construction practices in active projects, it was observed that the finished concrete surfaces remained exposed to evaporation for 30 to 40 minutes past final finish without application of an evaporation retarder. Also, ambient condition monitoring and evaporation remediation equipment (i.e., fog sprayer, etc.) were not present at the site. Such practices can significantly increase the risk of plastic shrinkage cracking. Average 
summer temperature highs in northern Pennsylvania are $29^{\circ} \mathrm{C}$ and the average summer lows are $17^{\circ} \mathrm{C}$. Average afternoon relative humidity readings are $53 \%$. The average winter high temperatures are $1^{\circ} \mathrm{C}$ and the average winter low temperatures are $-7^{\circ} \mathrm{C}$ with average afternoon relative humidity readings of $60 \%$. Without proper monitoring oversight of concrete placed in the afternoon during the summer, plastic shrinkage can be expected. The literature recommendation of application of the first layer of presoaked burlap 10 minutes after the strike-off and a second layer within 5 minutes [7] was not followed. The QA team mentioned that it has not mandated the contractor to adhere to strict moist curing practices on the dam rehabilitation projects. It could be reasoned that similar curing practices were followed by the same contractor on the past projects that experienced early age cracking.

4.3. Structural Design Factors. Upon review of the joint detail, the required longitudinal and transverse reinforcing steel in the bridge deck dam area was calculated based on both ACI 318-11 [56] and AASHTO LRFD, 2012 [60] requirements for temperature and shrinkage steel (Table 1). The calculations indicated that the actual bar area per foot of deck, based on the as-built drawings of past projects, was adequate. Also, diaphragm beams were consistently located below the concrete deck dam repair sections, providing substantial support to withstand the load at that location. The majority of reinforcing bar sizes were number 5 and number 6 , with a bar spacing of 6 inches. The deck cover thickness was between 50 and $75 \mathrm{~mm}$. These conditions match the literature recommendations $[5,6,10,35]$. Early age concrete cracking, therefore, is unlikely caused by structural design of the deck and reinforcing bars.

\section{Experimental Evaluation of Bridge Deck Concrete Mixtures}

The objectives of this task were to experimentally evaluate the cracking risk of concrete mixtures commonly used for bridge deck rehabilitation. These mixtures are denoted here as Mixture number 1 and Mixture number 2. Mixture number 1 was used on all the bridge decks that experienced early age concrete cracking. Mixture number 2 was subsequently developed and implemented by the state for use on bridge decks. With a reduction in the paste content and slight increase in the $\mathrm{w} / \mathrm{cm}$, it is demonstrated that Mixture number 2 provides a significant improvement in both field applications (no cracking) and laboratory experiments (demonstrated below), which is expected from the literature recommendations $[6,10,20]$. The experimental method provided herein can be used by future researchers to investigate the cracking propensity of their concrete mixtures.

5.1. Materials. Table 2 provides the concrete mixture proportions for Mixture number 1 and Mixture number 2. Mixture number 1 used a w/cm of 0.43 while Mixture number 2 used a w/cm of 0.44 . The coarse aggregate was an ASTM C33 number 57 crushed limestone with an oven dry (OD) specific gravity of 2.70 and absorption capacity of $0.23 \%$. The fine aggregate met ASTM C33 with an OD specific gravity of 2.52, absorption capacity of $2.02 \%$, and fineness modulus of 2.60 . Quarries were the same as outlined by previous bridge deck dam rehabilitation projects.

An ASTM C150 type I cement with an ASTM C989 grade 100 ground granulated blast furnace slag (GGBFS) as a $35 \%$ cement replacement by weight was used in both mixtures. The hydration of binary OPC-GGBFS binders, when compared to conventional $100 \%$ OPC binders, tend to have a reduced early age strength while the pozzolanic reaction allows the system to attain a similar or greater later age (28 and 90 days) strength. An air-entraining admixture, midrange water reducer, and set retarding admixture were used to achieve a target plastic air content of $6.0 \%$ and slump of $100 \mathrm{~mm}$.

5.2. Experimental Methodology and Results. The tests performed on the concrete mixtures were separated into three categories: (1) fresh properties (slump test: ASTM C14305a and plastic air content: ASTM C231-10), (2) mechanical properties (indirect tensile strength: ASTM C 496-11, uniaxial compressive strength: ASTM C 39-05, and elastic modulus: ASTM C469-10), and (3) shrinkage and temperature properties (drying shrinkage: ASTM C157-08, restrained ring shrinkage: ASTM C1581-09, heat of hydration: ASTM C106408, and coefficient of thermal expansion: ASTM C531-00). Since the $\mathrm{w} / \mathrm{cm}$ was greater than 0.42 , autogenous shrinkage was deemed negligible (60). A description of the experiments along with the results and discussion is provided below.

5.2.1. Fresh Properties. Slumps measured were between 89 and $115 \mathrm{~mm}$ and within the acceptable range of $100 \pm 38 \mathrm{~mm}$. The air content range was between $5.4 \%$ and $6.4 \%$. These values are adequate when compared to literature $[7,10,29$, $52,57]$ and within the acceptable range of $6.0 \pm 1.5 \%$.

5.2.2. Mechanical Properties. Mechanical property testing was performed using a standard load frame. All specimens were moist cured for their duration until moments before testing. Uniaxial compressive strength $\left(f_{c}^{\prime}\right)$ of concrete was measured at $1,3,7,28$, and 90 days. With the aid of a compressometer, the 1-, 7-, and 28-day elastic moduli (MOE) were obtained within the elastic region of the concrete stress-strain curve, from the $50 \mu \varepsilon$ point to $40 \%$ of the ultimate (failure) stress for each age (i.e., known as the chord modulus). The $f_{c}{ }^{\prime}$ and MOE measurements were obtained using $101 \times 203 \mathrm{~mm}$ concrete cylinders. Three duplicate specimens were cast for $f_{c}^{\prime}$ testing and two duplicate specimens were cast for MOE testing. The indirect tensile strength testing was performed on $150 \times 300 \mathrm{~mm}$ cylinders allowed to moist cure for 28 days before testing. The indirect tensile strength value recorded is the average of two duplicate specimens.

Table 3 provides the results of the mechanical properties testing. Mixture number 1 had a greater 7-, 28-, and 90day $f_{c}^{\prime}$ due to a lower $w / c m$. Mixture number 1 had a lower 1-day MOE. The two mixtures had comparable 7and 28-day MOE. The 28-day $f_{c}^{\prime}$ of Mixture number 1 and Mixture number 2 was $42.1 \mathrm{MPa}$ and $38.3 \mathrm{MPa}$, which are 
TABLE 1: Temperature and shrinkage steel calculations for bridge decks.

\begin{tabular}{|c|c|c|c|c|c|}
\hline $\begin{array}{l}\text { Job } \\
\text { number }\end{array}$ & $\begin{array}{l}\text { Bridge } \\
\text { number }\end{array}$ & Direction & $\begin{array}{l}\text { Bar area/foot of deck } \\
\left(\text { in }^{\wedge} 2 / f t\right)\end{array}$ & $\begin{array}{l}\text { ACI tempera- } \\
\text { ture/shrinkage } \\
\left(\mathrm{in}^{\wedge} 2 / \mathrm{ft}\right) \\
\end{array}$ & $\begin{array}{c}\text { LRFD } \\
\text { temperature/shrinkage } \\
\left(\text { in }^{\wedge} 2 / \mathrm{ft}\right) \\
\end{array}$ \\
\hline 1 & 1 & Westbound Pier 1 & 1.448 & 0.027 & 0.072 \\
\hline 1 & 1 & Westbound Pier 2 & 1.448 & 0.027 & 0.072 \\
\hline 1 & 1 & Westbound Pier 3 & 1.448 & 0.027 & 0.072 \\
\hline 1 & 1 & Eastbound Pier 1 & 1.448 & 0.029 & 0.076 \\
\hline 1 & 1 & Eastbound Pier 2 & 1.448 & 0.029 & 0.076 \\
\hline 1 & 1 & Eastbound Pier 3 & 1.448 & 0.029 & 0.076 \\
\hline 1 & 2 & Westbound Pier 1 (span 1) & 1.448 & 0.031 & 0.072 \\
\hline 1 & 2 & Westbound Pier 1 (span 2) & 1.448 & 0.029 & 0.068 \\
\hline 1 & 2 & Westbound Pier 2 (span 3) & 1.448 & 0.031 & 0.072 \\
\hline 1 & 2 & Westbound Pier 2 (Span 2) & 1.448 & 0.029 & 0.068 \\
\hline 1 & 2 & Eastbound Pier 1 (span 1) & 1.448 & 0.029 & 0.068 \\
\hline 1 & 2 & Eastbound Pier $1(\operatorname{span} 2)$ & 1.448 & 0.027 & 0.065 \\
\hline 1 & 2 & Eastbound Pier 2 (span 3) & 1.448 & 0.029 & 0.068 \\
\hline 1 & 2 & Eastbound Pier 2 (Span 2) & 1.448 & 0.027 & 0.065 \\
\hline 2 & 1 & Westbound Pier 1 & 1.37 & 0.031 & 0.085 \\
\hline 2 & 1 & Westbound Pier 2 & 1.37 & 0.031 & 0.085 \\
\hline 2 & 1 & Eastbound Pier 1 & 1.37 & 0.031 & 0.085 \\
\hline 2 & 1 & Eastbound Pier 2 & 1.37 & 0.031 & 0.085 \\
\hline 2 & 2 & Westbound Pier 1 & 1.448 & 0.029 & 0.076 \\
\hline 2 & 2 & Westbound Pier 2 & 1.448 & 0.029 & 0.076 \\
\hline 2 & 2 & Eastbound Pier 1 & 1.448 & 0.027 & 0.072 \\
\hline 2 & 2 & Eastbound Pier 2 & 1.448 & 0.027 & 0.072 \\
\hline 2 & 3 & Westbound Pier 1 (Span 1) & 1.696 & 0.029 & 0.068 \\
\hline 2 & 3 & Westbound Pier 1 (Span 2) & 1.696 & 0.027 & 0.065 \\
\hline 2 & 3 & Westbound Pier 2 (Span 2) & 1.448 & 0.027 & 0.065 \\
\hline 2 & 3 & Westbound Pier 2 (Span 3) & 1.448 & 0.029 & 0.068 \\
\hline 2 & 3 & Eastbound Pier 1 (Span 1) & 1.696 & 0.031 & 0.072 \\
\hline 2 & 3 & Eastbound Pier 1 (Span 2) & 1.696 & 0.027 & 0.065 \\
\hline 2 & 3 & Eastbound Pier 2 (Span 2) & 1.696 & 0.027 & 0.065 \\
\hline 2 & 3 & Eastbound Pier 2 (Span 3) & 1.696 & 0.029 & 0.068 \\
\hline 3 & 1 & Eastbound Pier 1 (Span 1) & 1.333 & 0.031 & 0.07 \\
\hline 3 & 1 & Eastbound Pier 2 (Span 1) & 1.333 & 0.031 & 0.07 \\
\hline 3 & 2 & Pier $1($ Span 1$)$ & 1.565 & 0.033 & 0.072 \\
\hline 3 & 2 & Pier 1 (Span 2) & 1.565 & 0.032 & 0.069 \\
\hline 3 & 2 & Pier 2 (Span 2) & 1.565 & 0.032 & 0.069 \\
\hline 3 & 2 & Pier 2 (Span 3) & 1.565 & 0.033 & 0.072 \\
\hline 3 & 3 & Pier 1 (Span 1) & 1.565 & 0.033 & 0.072 \\
\hline 3 & 3 & Pier 1 (Span 2) & 1.565 & 0.032 & 0.069 \\
\hline 3 & 3 & Pier 2 (Span 2) & 1.565 & 0.032 & 0.069 \\
\hline 3 & 3 & Pier 2 (Span 3) & 1.565 & 0.033 & 0.072 \\
\hline 3 & 4 & Pier 1 (Span 1) & 1.565 & 0.035 & 0.075 \\
\hline 3 & 4 & Pier 1 (Span 2) & 1.565 & 0.033 & 0.072 \\
\hline 3 & 4 & Pier 2 (Span 2) & 1.565 & 0.033 & 0.072 \\
\hline 3 & 4 & Pier 2 (Span 3) & 1.565 & 0.035 & 0.075 \\
\hline
\end{tabular}


TABLE 2: Mixture proportions and experimental results for Mixture number 1 and Mixture number 2 .

\begin{tabular}{|c|c|c|}
\hline & $\begin{array}{c}\text { Mixture number } 1 \\
\text { Proportions by } \\
\text { weight } \mathrm{kg} / \mathrm{m}^{3}\end{array}$ & $\begin{array}{c}\text { Mixture number } 2 \\
\text { Proportions by } \\
\text { weight } \mathrm{kg} / \mathrm{m}^{3}\end{array}$ \\
\hline Cementitious material & 390 & 362 \\
\hline Cement & 254 & 236 \\
\hline GGBFS & 136 & 127 \\
\hline Water ${ }^{*}$ & 168 & 160 \\
\hline Coarse aggregate & 1103 & 1103 \\
\hline Fine aggregate & 603 & 645 \\
\hline $\mathrm{w} / \mathrm{cm}$ & 0.43 & 0.44 \\
\hline $\begin{array}{l}\text { Cementitious paste } \\
\text { Content (\%) }\end{array}$ & 35.6 & 33.8 \\
\hline $\begin{array}{l}\text { Peak heat of hydration } \\
\left({ }^{\circ} \mathrm{C}\right)\end{array}$ & 36 & 36 \\
\hline $\begin{array}{l}\text { Concrete COTE } \\
\left(\text { strain } /{ }^{\circ} \mathrm{C}\right)\end{array}$ & $8.69 E-06$ & $8.44 E-06$ \\
\hline Thermal strain $(\mu \varepsilon)$ & 116 & 113 \\
\hline $\begin{array}{l}\text { Unrestrained drying } \\
\text { Shrinkage }(\mu \varepsilon)\end{array}$ & 418 & 378 \\
\hline $\begin{array}{l}\text { 28-day indirect tensile } \\
\text { strength }\end{array}$ & 2.59 & 2.82 \\
\hline $\begin{array}{l}\text { Age of cracking during } \\
\text { restrained ring test (day) }\end{array}$ & $>28,11,15$ & $>40,>40,>40$ \\
\hline $\begin{array}{l}\text { Average stress rate for } \\
\text { restrained ring test } \\
(\mathrm{MPa} / \text { day })\end{array}$ & 0.19 & 0.08 \\
\hline
\end{tabular}

${ }^{*}$ Including the water mass necessary to saturate aggregates.

considerably larger than the structural design requirements of $27.6 \mathrm{MPa}$ and the literature recommendations of 20.7 to 31.0 MPa for bridge deck applications [6]. The reduced early age stiffness of Mixture number 2 assists in preventing early age cracking. The reduced paste content and pozzolanic reaction of the binary OPC-GGBFS system facilitate reduced early age stiffness while still obtaining later age stiffness and strength values that allow the carrying of loads necessary for vehicular traffic. Also, these binary systems create a complex microstructure that makes the system more resistant to moisture and chloride ingress [31]. As mentioned before, high compressive strengths are generally attributed to low $\mathrm{w} / \mathrm{cm}$ and higher cement contents. These conditions favor higher stress development and higher cracking risk of concrete due to a higher heat of hydration, higher drying shrinkage, higher modulus of elasticity, and lower creep. Overall, the use of excessively strong concretes should be avoided and may contribute to the cracking noticed in this study. Table 2 shows Mixture number 2 was developed for better performance by reducing the paste content. Also, Table 3 shows Mixture number 2 has a greater tensile strength than Mixture number 1 (2.59 MPa and 2.82 MPa, resp.). This greater tensile strength may also assist in the reduced cracking propensity of Mixture number 2.
5.2.3. Shrinkage and Temperature Properties. The heat of hydration of fresh concrete was measured according to ASTM C1064-08, using type $\mathrm{T}$ thermocouples placed mid-height of well-insulated $152 \times 152 \mathrm{~mm}$ concrete cylinders. Before the test, all type $\mathrm{T}$ thermocouples were calibrated in the temperature range $0-60^{\circ} \mathrm{C}$. The thermocouple output was recorded automatically by a data acquisition unit once every 30 minutes after casting concrete. Two specimens were tested for each mixture.

The coefficient of thermal expansion (COTE) was measured using equivalent mortar specimens in a saturated condition according to ASTM C531-00. Mortar bars ( $(25 \times$ $25 \times 280 \mathrm{~mm}$ ) according to ASTM C490-11) were prepared by excluding the coarse aggregates from the previously developed concrete mixtures. This is specified by ASTM C531 to limit the temperature gradients that could develop in larger concrete prisms ( $75 \times 75 \mathrm{~mm}$ cross section). Mortars were mixed according to ASTM C305-06 and cast in prism molds using a vibrating table. Gage studs were placed at the opposite $25 \times 25 \mathrm{~mm}$ ends to facilitate length measurements. Testing began after the specimens were moist cured for 14 days. The results from four duplicate prisms were used and averaged to determine the COTE of each mixture in the saturated condition. The saturated specimens were heated to a temperature of $80^{\circ} \mathrm{C}$ while being fully submerged in saturated lime-water bath. After at least 16 hours at $80^{\circ} \mathrm{C}$, the specimens' length was recorded to the nearest $0.0025 \mathrm{~mm}$. The specimens were then submerged back into the limewater bath and cooled to a temperature of $60^{\circ} \mathrm{C}$. After at least 16 hours at $60^{\circ} \mathrm{C}$, the specimens' lengths were recorded. This temperature cycle $\left(80^{\circ} \mathrm{C}\right.$ to $60^{\circ} \mathrm{C}$ and reverse) was continued until the specimens reached a constant length upon cooling to $60^{\circ} \mathrm{C}$. This took approximately $1-3$ weeks. Once a constant length was achieved at $60^{\circ} \mathrm{C}$, prism shrinkage ceased and the true COTE was obtained.

For drying shrinkage, concrete specimens were cast in $75 \times 75 \times 280 \mathrm{~mm}$ rectangular molds with embedded studs. Three duplicate specimens were tested for each mixture. The initial length measurements were upon demolding at 24 hours with a comparator. After initial measurements, the specimens were submerged in a limewater bath for 27 days. After the curing period was complete, the specimens' length was measured and drying commenced. The specimens were allowed to dry in an ambient condition of $22.8 \pm 1^{\circ} \mathrm{C}$ and $50 \pm$ $5 \% \mathrm{RH}$. Comparator length measurements were performed periodically, with the final measurements occurring 157 days after casting (i.e., total drying time was 129 days).

The restrained shrinkage of the two mixtures was measured using a restrained ring test per ASTM C1581-09. The test setup includes a concrete annulus that is cast around a steel ring. After 24 hours of curing under wet burlap, the specimens were demolded by removing the exterior cardboard mold. The concrete top surface was then sealed with aluminum tape, which allowed the concrete to dry from its outside circumference inside an environmental chamber that controlled the ambient conditions at $22.8 \pm 0.5^{\circ} \mathrm{C}$ and $50 \pm 2 \%$ $\mathrm{RH}$. The resulting shrinkage deformations were measured by four symmetrically placed strain gages, mounted on the inner surface of the steel ring (at mid-height). These data allow 
TABLE 3: Compressive strength and elastic modulus of Mixture number 1 and Mixture number 2.

\begin{tabular}{|c|c|c|c|c|}
\hline \multirow{2}{*}{ AGE } & \multicolumn{2}{|c|}{ Mixture number $1(\mathrm{w} / \mathrm{cm}=0.43)$} & \multicolumn{2}{|c|}{ Mixture number $2(\mathrm{w} / \mathrm{cm}=0.44)$} \\
\hline & Compressive strength: $\mathrm{MPa}$ & Elastic modulus: $\mathrm{MPa}$ & Compressive strength: $\mathrm{MPa}$ & Elastic modulus: $\mathrm{MPa}$ \\
\hline 1 & 10.9 & $2.01 E 04$ & 11.0 & $1.75 E 04$ \\
\hline 3 & 21.2 & - & 21.3 & - \\
\hline 7 & 28.7 & $3.18 E 04$ & 26.1 & $3.22 E 04$ \\
\hline 28 & 42.1 & $3.69 E 04$ & 38.3 & $3.69 E 04$ \\
\hline 90 & 43.1 & - & 40.9 & - \\
\hline
\end{tabular}

calculation of the tensile stresses that develop inside concrete as a result of restrained shrinkage. As the stresses inside the concrete grow with time, the stresses may eventually reach the tensile strength of the material, leading to concrete cracking. The age at which cracking occurs and the stress magnitude at the time of cracking provide a good indication of the susceptibility of the concrete mixture to early age cracking. Three duplicate ring specimens were cast for each mixture.

Table 2 provides the results for the temperature and shrinkage property experiments. The peak heat of hydration was approximately $36.1^{\circ} \mathrm{C}$ for both mixtures. This temperature is reasonable for type I cement with 35\% GGBFS replacement by weight [31]. The COTE provided in Table 2 is the estimated concrete COTE that is calculated using the law of mixtures (31) based on the measured mortar COTE, the volume fraction of coarse aggregates, and the COTE of limestone coarse aggregates $\left(6 E-06 /{ }^{\circ} \mathrm{C}\right)$. The measured mortar COTE values for Mixtures number 1 and number 2 were $10.51 E-06 /{ }^{\circ} \mathrm{C}$ and $10.12 E-06 /{ }^{\circ} \mathrm{C}$, respectively. Therefore, the concrete COTE for Mixtures number 1 and number 2 can be calculated as $8.69 E-06 /{ }^{\circ} \mathrm{C}$ and $8.44 E-06 /{ }^{\circ} \mathrm{C}$, respectively. It should be noted that Mixture number 1 was anticipated to show a greater COTE based on its greater paste content.

Thermal strains were estimated based on the COTE and the peak temperature resulting from the heat of hydration $\left(36.1^{\circ} \mathrm{C}\right)$, assuming that the concrete eventually cools down to the ambient temperature of $22.8^{\circ} \mathrm{C}$. For Mixtures number 1 and number 2 , the resultant thermal contraction strains were approximately $116 \mu \varepsilon$ and $113 \mu \varepsilon$, respectively, as noted in Table 2. The table also provides the results of unrestrained drying shrinkage measurements. The ultimate drying shrinkage (at 129 days of drying) was recorded for Mixture number 1 as $418 \mu \varepsilon$ and for Mixture number 2 as $378 \mu \varepsilon$. The drying shrinkage evolution for these mixtures is presented in Figure 2. These values are in agreement with typical literature results for concrete containing moderate levels of GGBFS [46, 61].

Table 2 also presents the results for the restrained ring shrinkage test. For Mixture number 1, cracking occurred at 11 days (at a maximum steel strain level of $-35 \mu \varepsilon$ ) for ring 2 and at 15 days (at a maximum steel strain level of $-34 \mu \varepsilon$ ) for ring 3 , while no cracking occurred up to 28 days for ring 1 , although the steel strain climbed to $-42 \mu \varepsilon$ at this age for ring 1 . The strain development between all three rings was consistent. The phenomenon of only one ring not exhibiting cracking has been observed before and does not indicate inaccuracy of the test method [62] but corresponds to inherent material

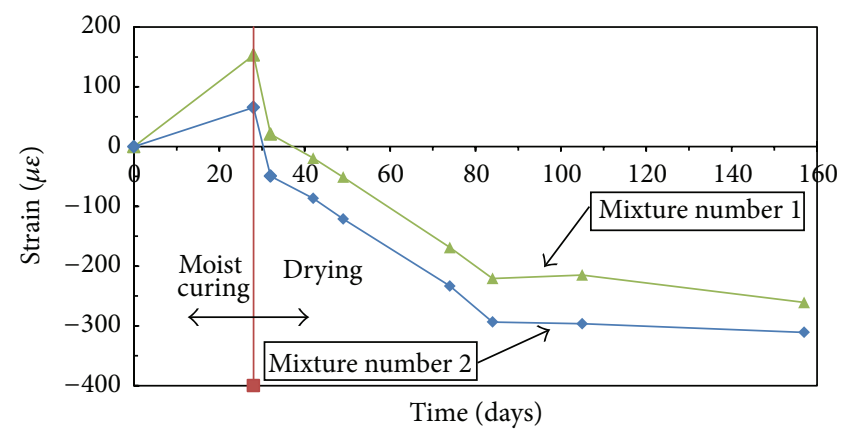

FIGURE 2: Drying shrinkage strain development over time for Mixture number 1 and Mixture number 2.

variability of concrete. For Mixture number 2, the strain development between the rings was consistent. At 28 days, ring 1 and ring 2 had a maximum steel strain level of $-56 \mu \varepsilon$, while ring 3 had a maximum steel strain level of $-53 \mu \varepsilon$. At the termination of the test at 40 days, no cracking was observed in the rings for Mixture number 2.

According to ASTM C1581-09, an average stress rate at cracking can be determined based on the elapsed time at cracking, or, if no cracks are visible, the last day of testing. The average magnitude of the restrained shrinkage stress rate for the two mixtures was calculated accordingly and is provided in Table 2. The strain development over time is presented in Figure 3 for Mixture number 1 and Figure 4 for Mixture number 2. Please note the strain value jumps in Figure 4 at 14 days and 28 days are artifacts of the DAQ and not cracking of the concrete. The average calculated stress rate for Mixture number 1 is $0.19 \mathrm{MPa} /$ day, which indicates a moderate to high potential for cracking, according to ASTM C1581, where cracking is expected for specimens between the ages of 7 and 14 days. The average calculated stress rate for Mixture number 2 is $0.08 \mathrm{MPa} /$ day, indicating a low potential for cracking, where cracking is not expected within the first 28 days. The reduced paste content and slightly higher $\mathrm{w} / \mathrm{cm}$ of Mixture number 2 resulted in lower shrinkage and lower risk of cracking. Considering that Mixture number 1 was implemented on all bridge decks that exhibited early age cracking, the results obtained here indicate that a transition to Mixture number 2, along with its decreased paste content and higher $\mathrm{w} / \mathrm{cm}$, improves the durability against early deck cracking in field applications. 


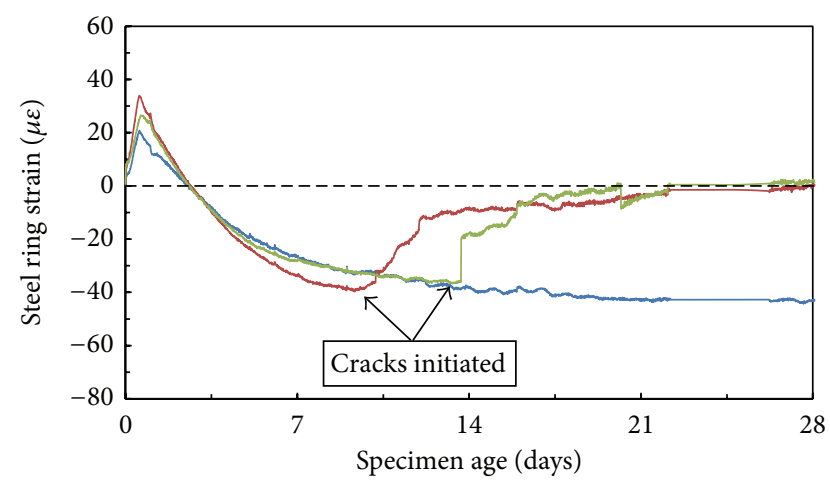

FIGURE 3: Restrained ring strain development over time for Mixture number 1. Each line denotes the average of four (4) strain readings for one ring. Three (3) rings were tested.

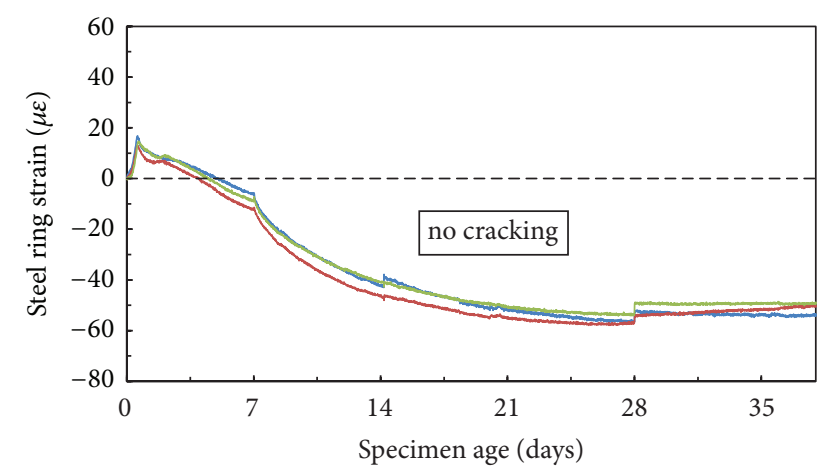

FIGURE 4: Restrained ring strain development over time for Mixture number 2. Each line denotes the average of four (4) strain readings for one ring. Three (3) rings were tested.

\section{Conclusions}

The main objective of this research was to identify the causes of longitudinal early age cracking in concrete deck segments placed adjacent to the newly replaced bridge deck expansion joints and to provide a blueprint of steps necessary to perform this type of investigation. The steps consisted of (1) a literature review of the causes of early age cracking on bridge decks, (2) a review of past and active bridge deck rehabilitation projects, and (3) an experimental evaluation of the two most commonly used bridge deck concrete mixtures.

The following conclusions can be stated.

(i) The most likely causes of the observed early age cracking are inadequate moist curing practices and failure to properly eliminate the risk of plastic shrinkage cracking during construction. Moist curing must start as soon as possible and proper remediation techniques must be readily available at the construction site to limit the rate of water evaporation from the surface of fresh concrete.

(ii) The 28-day $f_{c}{ }^{\prime}$ of the placed concrete exceeded the required structural design strength of $27.6 \mathrm{MPa}$ by up to $43 \%$. Also, the measured slumps were in excess of $200 \mathrm{~mm}$. These excessive strength and slump values further exacerbate the risk of early age cracking. Construction specifications should include language to limit the maximum allowable compressive strength and slump of concrete and to evaluate the concrete for early age shrinkage cracking.

(iii) A comprehensive experimental evaluation of bridge deck concrete mixtures showed that Mixture number 2 performs better against early age cracking. A lower cement paste content, lower COTE, lower drying shrinkage, and lower compressive strength are factors that have improved the performance of Mixture number 2 .

(iv) A review of the structural design of the deck and reinforcing bars suggested that the observed early age cracking was not likely caused by the structural design factors.

Overall, an integrated approach, to ensure proper selection and design of concrete materials, proper structural design of the deck (including the repair section), and proper construction and curing methods, is needed to minimize early age cracking of concrete deck and repair sections. Construction specifications and quality assurance practices must be updated as needed to benefit from the available knowledge in the literature to prevent early age cracking. Further research is needed to quantify the effect of cracks on the durability and service-life expectancy of bridge decks and to identify the best remediation techniques and the optimum time to repair the existing cracked bridge decks.

\section{Conflict of Interests}

The authors declare that there is no conflict of interests regarding the publication of this paper.

\section{Acknowledgments}

The experiments performed during this research occurred at Penn State's Civil Infrastructure Testing and Evaluation Laboratory (CITEL) and Villanova University's Structural Engineering Teaching and Research Laboratory. The research team would like to thank the Pennsylvania Department of Transportation (PennDOT) personnel who contributed to the success of this project, specifically Mr. Paul King, the project's technical advisor. The authors thank Ms. Danielle Lombardi, Mr. Dennis Morian, Mr. Chris Cartwright, Dr. Shervin Jahangirnejad, Mr. Michael Salera, and Mr. Dan Fura for their assistance and insight. The authors also thank Mr. Michael Casper of Penn State for his thorough editorial review. This paper consists of the major finding of the Final Project Report no. FHWA-PA-2012-006-100303, submitted to PennDOT. The contents of this report reflect the views of the authors, who are responsible for the facts and the accuracy of the information presented herein. This document is disseminated under the sponsorship of the US Department of Transportation's University Transportation Centers Program, in the interest of information exchange. The US Government assumes no liability for the contents or use thereof. 


\section{References}

[1] K. Babaei and R. Purvis, "Prevention of cracks in concrete bridge decks: report on Laboratory Investigation of Concrete Shrinkage," Research Project 89-01, Pennsylvania Department of Transportation, Harrisburg, Pa, USA, 1994.

[2] M. Brown, G. Sellers, K. Folliard, and D. Fowler, Restrained Shrinkage Cracking of Concrete Bridge Decks: State-of-the-Art Review, Texas Department of Transportation, Austin, Tex, USA, 2001.

[3] K. Folliard, Use of Innovative Materials to Control Restrained Shrinkage Cracking in Concrete Bridge Decks, Texas Department of Transportation, Austin, Tex, USA, 2003.

[4] R. Frosch, D. T. Blackman, and R. D. Radabaugh, Investigation of Bridge Deck Cracking in Various Bridge Superstucture Systems, Purdue University, West Layfayette, Ind, USA, 2003.

[5] T. Kochanaski, J. Parry, D. Pruess, L. Schuchardt, and J. Ziehr, "Premature cracking of concrete bridge decks study," Final Report, Wisconsin Department of Transportation, Madison, Wis, USA, 1990.

[6] P. Krauss and E. Rogalla, "Transverse cracking in newly constructed bridge decks," NCHRP Report 380, Transportation Research Board, Washington, DC, USA, 1996.

[7] H. A. K. McLeod, D. Darwin, and J. Browning, "Development and construction of Low-Cracking High Performance Concrete (LC-HPC) bridge decks: construction methods, specifications, and resistance to chloride ion penetration," SM Report 94, University of Kansas Center for Research, Lawrence, Kan, USA, 2009.

[8] C. Meyers, "Survey of cracking on underside of classes B-1 and B-2 concrete bridge decks in district 4," Investigation 822, Division of Material and Research, Missouri Highway and Transportation Department, Jefferson City, Miss, USA, 1982.

[9] J. B. Poppe, "Factors affecting the durability of concrete bridge decks," Tech. Rep. FHWA/CA/SD-81/2, Division of Transportation Facilities, California Department of Transportation, Sacramento, Calif, USA, 1981.

[10] T. R. Schmitt and D. Darwin, "Cracking in concrete bridge decks," Tech. Rep. K-TRAN:KU-94-1, Kansas Department of Transportation, Topeka, Kan, USA, 1995.

[11] R. Maggenti, C. Knapp, and S. Fereira, "Controlling shrinkage cracking: available technologies can provide nearly crack-free concrete bridge decks," Concrete International, vol. 35, no. 7, pp. 36-41, 2013.

[12] P. Zhu and Z. J. Ma, "Selection of durable closure pour materials for accelerated bridge construction," Journal of Bridge Engineering, vol. 15, no. 6, pp. 695-704, 2010.

[13] D. H. Chen and M. Won, "Field performance monitoring of repair treatments on joint concrete pavements," Journal of Testing and Evaluation, vol. 36, no. 2, pp. 119-127, 2008.

[14] M. M. Sprinkel, R. Weyers, C. Blevins, A. Ramniceanu, and S. A. Weyers, "Failure and repair of deck closure pour on interstate 81," Transportation Research Record, no. 2150, pp. 119-128, 2010.

[15] D. Cusson and N. Mailvaganam, "Durability of repair materials," Concrete International, vol. 18, no. 3, pp. 34-38, 1996.

[16] G. Tsiatas and J. Robinson, "Durability evaluation of concrete crack repair systems," Transportation Research Record, no. 1795, pp. 82-87, 2002.

[17] N. K. Emberson and G. C. Mays, "Significance of property mismatch significance of property mismatch in the patch repair of structural concrete, part 1: properties of repair systems,"
Magazine of Concrete Research, vol. 42, no. 152, pp. 147-160, 1990.

[18] D. Darwin, J. Browning, and W. D. Lindquist, "Control of cracking in bridge decks: observations from the field," Cement, Concrete and Aggregates, vol. 26, no. 2, pp. 148-154, 2004.

[19] D. P. Bentz, P. Lura, and J. W. Roberts, "Mixture proportioning for internal curing," Concrete International, vol. 27, no. 2, pp. 3540, 2005.

[20] M. A. Saadeghvaziri and R. Hadidi, "Transverse cracking of concrete bridge decks: effects of design factors," Journal of Bridge Engineering, vol. 10, no. 5, pp. 511-519, 2005.

[21] C. French, L. Eppers, Q. Le, and J. F. Hajjar, "Transverse cracking in concrete bridge decks," Transportation Research Record, no. 1688, pp. 21-29, 1999.

[22] T. R. Schmitt and D. Darwin, "Effect of material properties on cracking in bridge decks," Journal of Bridge Engineering, vol. 4, no. 1 , pp. 8-13, 1999.

[23] P. K. Mehta and P. J. M. Monteiro, Concrete: Microstructure, Properties, and Materials, McGraw Hill, New York, 3rd edition, 2006.

[24] M. Grzybowski and S. P. Shah, "Shrinkage cracking of fiber reinforced concrete," ACI Materials Journal, vol. 87, no. 2, pp. 138-148, 1990.

[25] C. Qi, J. Weiss, and J. Olek, "Characterization of plastic shrinkage cracking in fiber reinforced concrete using image analysis and a modified Weibull function," Materials and Structures, vol. 36, no. 260, pp. 386-395, 2003.

[26] N. Banthia and R. Gupta, "Influence of polypropylene fiber geometry on plastic shrinkage cracking in concrete," Cement and Concrete Research, vol. 36, no. 7, pp. 1263-1267, 2006.

[27] B. Kim and W. J. Weiss, "Using acoustic emission to quantify damage in restrained fiber-reinforced cement mortars," Cement and Concrete Research, vol. 33, no. 2, pp. 207-214, 2003.

[28] F. H. Dakhil and P. D. Cady, "Cracking of fresh concrete as related to reinforcement," ACI Journal, vol. 72, no. 8, pp. 421428, 1975.

[29] M. A. Saadeghvaziri and R. Hadidi, "Cause and control of transverse cracking in concrete bridge decks," Final Report FHWA-NJ-2002-19, Federal Highway Administration, Washington, DC, USA, 2002.

[30] Portland Cement Association, Durability of Concrete Bridge Decks: A Cooperative Study-Final Report, Portland Cement Association, Skokie, Ill, USA, 1970.

[31] S. Mindess, J. F. Young, and D. Darwin, Concrete, Pearson Education, Upper Saddle River, NJ, USA, 2nd edition, 2003.

[32] American Concrete Institute, ACI 231-10: Early-Age Cracking: Causes, Measurement, and Mitigation, American Concrete Institute, Farmington Hills, Mich, USA, 2010.

[33] K. A. Riding, J. L. Poole, A. K. Schindler, M. C. G. Juenger, and K. J. Folliard, "Evaluation of temperature prediction methods for mass concrete members," ACI Materials Journal, vol. 103, no. 5, pp. 357-365, 2006.

[34] American Concrete Institute, ACI 224R-01: Control of Cracking in Concrete Structures, American Concrete Institute, Farmington Hills, Mich, USA, 2001.

[35] New York State Department of Transportation, "The state of the art bridge deck," Final Report, The Bridge Deck Task Force, Albany, NY, USA, 1995.

[36] Z. Grasley, Internal relative humidity, drying stress gradients, and hygrothermal dilation of concrete [M.S. thesis], University of Illinois at Urbana-Champaign, Champaign, Ill, USA, 2003. 
[37] S. L. Meyers, "Thermal coefficient of expansion of Portland cement-long time test," Industrial and Engineering Chemistry, vol. 32, no. 8, pp. 1107-1112, 1940.

[38] M. Won, "Improvements of testing procedures for concrete coefficient of thermal expansion," Transportation Research Record, no. 1919, pp. 23-28, 2005.

[39] C. G. Zoldners, Thermal Properties of Concrete under Sustained Elevated Temperatures, Temperature and Concrete, ACI Publication SP-25, 1971.

[40] A. Radocea, "Model of plastic shrinkage," Magazine of Concrete Research, vol. 46, no. 167, pp. 125-132, 1994.

[41] M. D. Cohen, J. Olek, and W. L. Dolch, "Mechanism of plastic shrinkage cracking in portland cement and portland cementsilica fume paste and mortar," Cement and Concrete Research, vol. 20, no. 1, pp. 103-119, 1990.

[42] C. Ozyildirim, "Comparison of the air contents of freshly mixed and hardened concretes," Cement, Concrete and Aggregates, vol. 13, no. 1, pp. 11-17, 1991.

[43] P. Lura, K. van Breugel, and I. Maruyama, "Effect of curing temperature and type of cement on early-age shrinkage of highperformance concrete," Cement and Concrete Research, vol. 31, no. 12, pp. 1867-1872, 2001.

[44] K. M. Lee, H. K. Lee, S. H. Lee, and G. Y. Kim, "Autogenous shrinkage of concrete containing granulated blast-furnace slag," Cement and Concrete Research, vol. 36, no. 7, pp. 1279-1285, 2006.

[45] D. P. Bentz and O. M. Jensen, "Mitigation strategies for autogenous shrinkage cracking," Cement and Concrete Composites, vol. 26, no. 6, pp. 677-685, 2004.

[46] S. H. Kosmatka and M. L. Wilson, Design and Control of Concrete Mixtures, Portland Cement Association, Skokie, Ill, USA, 15th edition, 2011.

[47] A. Radlinska, F. Rajabipour, B. Bucher, R. Henkensiefken, G. Sant, and J. Weiss, "Shrinkage mitigation strategies in cementitious systems: a closer look at differences in sealed and unsealed behavior," Transportation Research Record, no. 2070, pp. 59-67, 2008.

[48] F. Rajabipour, G. Sant, and J. Weiss, "Interactions between Shrinkage Reducing Admixtures (SRA) and cement paste's pore solution," Cement and Concrete Research, vol. 38, no. 5, pp. 606615, 2008.

[49] J. Weiss, P. Lura, F. Rajabipour, and G. Sant, "Performance of shrinkage-reducing admixtures at different humidities and at early ages," ACI Materials Journal, vol. 105, no. 5, pp. 478-486, 2008.

[50] K. J. Folliard and N. S. Berke, "Properties of high-performance concrete containing shrinkage-reducing admixture," Cement and Concrete Research, vol. 27, no. 9, pp. 1357-1364, 1997.

[51] P. Lura, B. Pease, G. B. Mazzotta, F. Rajabipour, and J. Weiss, "Influence of shrinkage-reducing admixtures on development of plastic shrinkage cracks," ACI Materials Journal, vol. 104, no. 2, pp. 187-194, 2007.

[52] M. A. Issa, "Investigation of cracking in concrete bridge decks at early ages," Journal of Bridge Engineering, vol. 4, no. 2, pp. 116$124,1999$.

[53] American Concrete Institute, Guide to Curing Concrete, ACI 308R-01, American Concrete Institute, Farmington Hills, Mich, USA, 2001.

[54] F. H. Wittmann, "On the action of capillary pressure in fresh concrete," Cement and Concrete Research, vol. 6, no. 1, pp. 49$56,1976$.
[55] G. E. Ramey, A. R. Wolff, and R. L. Wright, "Structural design actions to mitigate bridge deck cracking," Practice Periodical on Structural Design and Construction, vol. 2, no. 3, pp. 118-124, 1997.

[56] American Concrete Institute, Building Code Requirements for Structural Concrete, ACI 318R-11, American Concrete Institute, Farmington Hills, Mich, USA, 2011.

[57] K. Babaei and N. Hawkins, "Evaluation of bridge deck protective strategies," NCHRP Report 297, Transportation Research Record, Washington, DC, USA, 1987.

[58] D. P. Bentz, O. M. Jensen, K. K. Hansen, J. F. Olesen, H. Stang, and C.-J. Haecker, "Influence of cement particle-size distribution on early age autogenous strains and stresses in cement-based materials," Journal of the American Ceramic Society, vol. 84, no. 1, pp. 129-135, 2001.

[59] T. T. Cheng and D. W. Johnson, "Incident assessment of transverse cracking in bridge decks: construction and material consideration," Tech. Rep. FHWA/NC/85-002, vol. 1, Federal Highway Administration, Washington, DC, USA, 1985.

[60] AASHTO LRFD Bridge Design Specifications, American Association of State Highway and Transportation Officials, Washington, DC, USA, 6th edition, 2012.

[61] E. Tazawa, A. Yonekura, and S. Tanaka, Drying Shrinkage and Creep of Concrete Containing Granulated Blast Furnace Slag, ACI SP114-64, American Concrete Institute, Farmington Hills, Mich, USA, 1989.

[62] A. Radlinska, Reliability-based analysis of early-age cracking in concrete [Ph.D. thesis], Purdue University, West Lafayette, Ind, USA, 2008. 

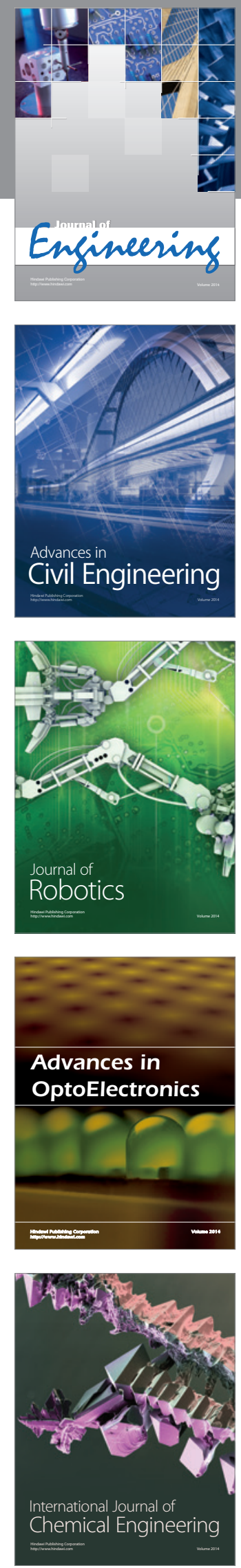

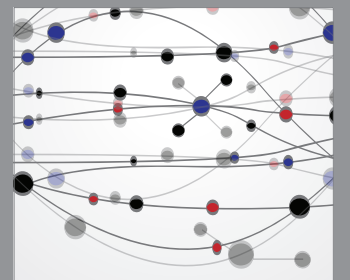

The Scientific World Journal
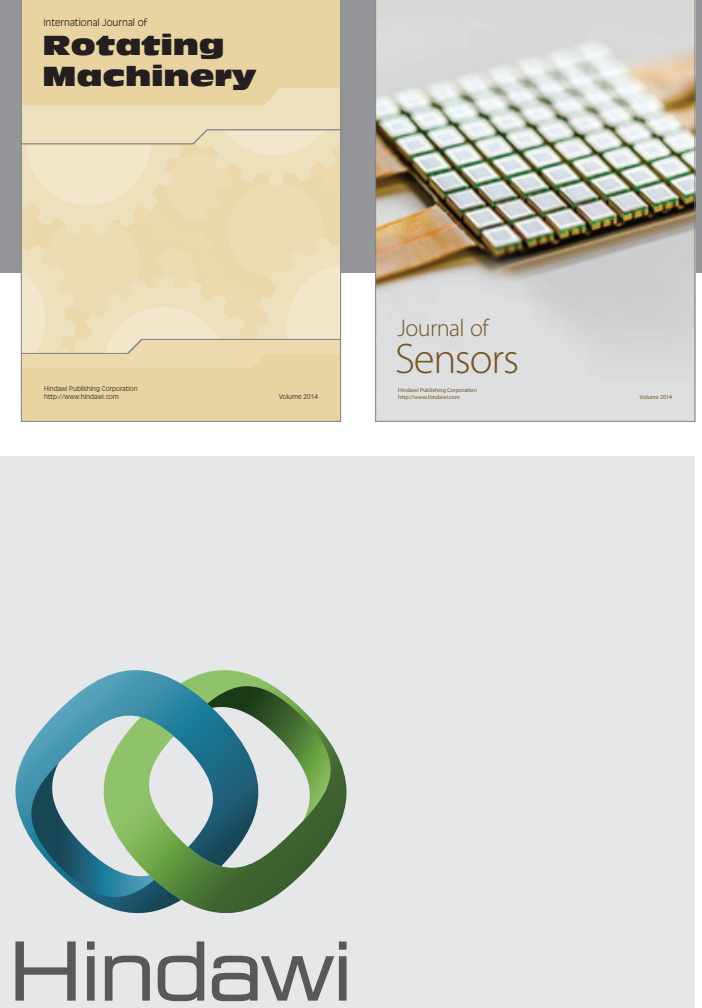

Submit your manuscripts at http://www.hindawi.com
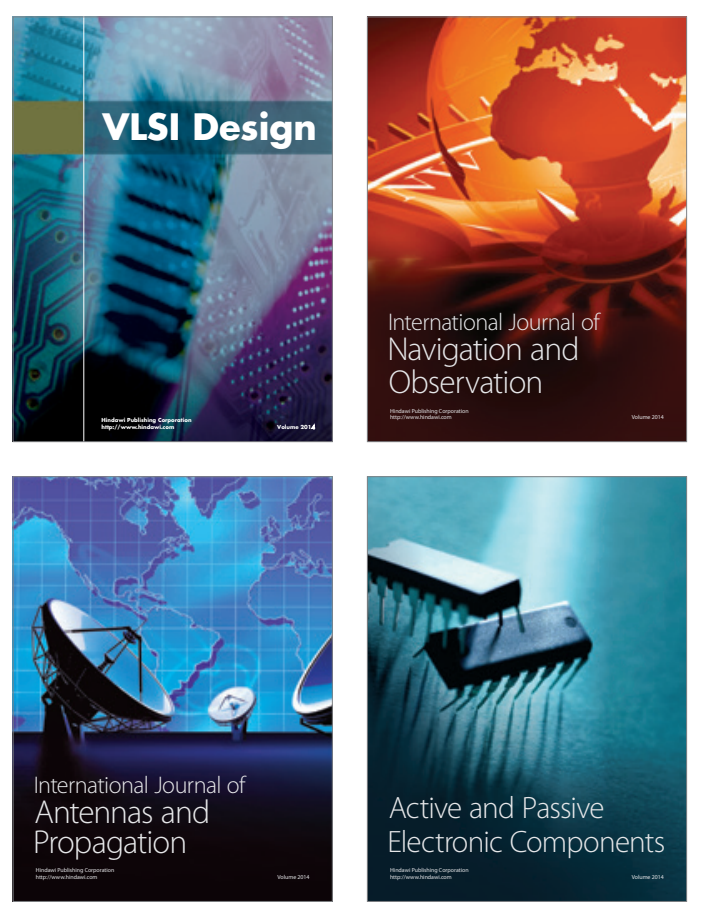
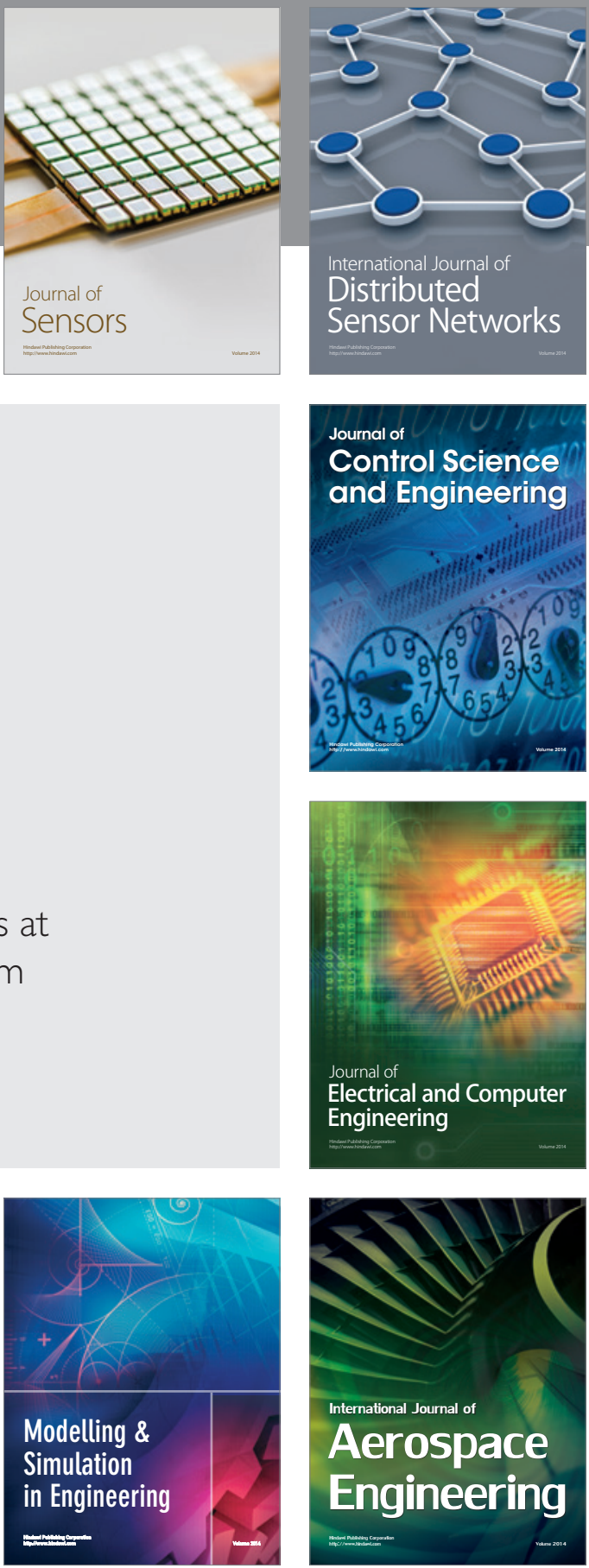

Journal of

Control Science

and Engineering
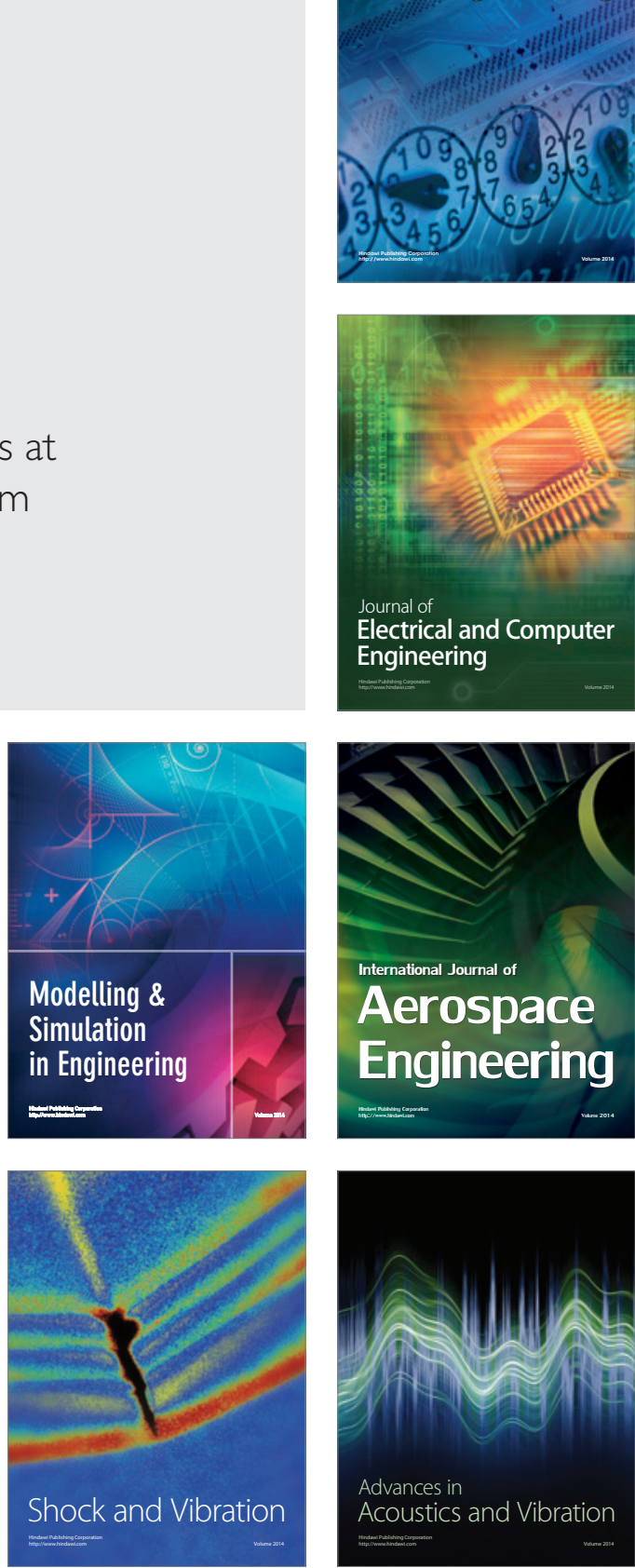